\title{
Keselamatan Diri dalam Qurban Idul Adha 1441 H sebagai Bentuk Pengabdian kepada Masyarakat Politeknik Penerbangan Palembang
}

\author{
Anton Abdullah \\ Program Studi DIII Penyelamatan dan Pemadam Kebakaran Penerbangan \\ Politeknik Penerbangan Palembang \\ e-mail:anton@poltekbangplg.ac.id \\ Wildan Nugraha \\ Program Studi DIII Penyelamatan dan Pemadam Kebakaran Penerbangan \\ Politeknik Penerbangan Palembang \\ e-mail:wildan.nugraha@poltekbangplg.ac.id \\ Fitri Masitoh \\ Program Studi DIII Penyelamatan dan Pemadam Kebakaran Penerbangan \\ Politeknik Penerbangan Palembang \\ e-mail: fitri@poltekbangplg.ac.id \\ Sutiyo \\ Program Studi DIII Penyelamatan dan Pemadam Kebakaran Penerbangan \\ Politeknik Penerbangan Palembang \\ e-mail:sutiyo@poltekbangplg.ac.id \\ Rinto Astutik \\ Program Studi DIII Penyelamatan dan Pemadam Kebakaran Penerbangan \\ Politeknik Penerbangan Palembang \\ e-mail: rinto.astutik@poltekbangplg.ac.id
}

\begin{abstract}
Abstrak
Target dan luaran dari kegiatan ini adalah untuk melaksanakan Tridharma Perguruan Tinggi, pengabdian masyarakat bagi dosen di lingkungan Politeknik Penerbangan Palembang, Sumatera Selatan. Metode kegiatan yang digunakan adalah 1) ceramah agama, yaitu memberikan bimbingan rohani kepada keluarga besar Politeknik Penerbangan dan warga sekitar; 2) lecturing di mana narasumber menjelaskan kepada keluarga besar Politeknik Penerbangan dan warga sekitar tentang hikmah berkurban dan meneladani syari'at Nabi Ibrahim As., menumbuhkan kesadaran dan peran serta keluarga besar Politeknik Penerbangan dan warga sekitar dalam menumbuhkan kecintaan kepada sesama dalam perwujudan rasa sukur dan taqwa kepada Allah Swt.; dan 3) evidence-based learning, dimana para pengkurban dan tim pelaksana diajak untuk bersama-sama bagaimana cara pengumpulan, penyembelihan, dan pembagian hewan kurban. Hasil yang diperoleh dari kegiatan ini dapat membuat tim pelaksana, keluarga besar Politeknik Penerbangan dan warga sekitar yaitu: 1) meneladani syari'at Nabi Ibrahim AS; 2) menumbuhkan kesadaran dan peran serta umat Islam (dosen) dalam menumbuhkan kecintaan kepada sesama dalam perwujudan taqwa kepada Allah Swt.; 3) mengabdi kepada masyarakat dalam memperkokoh tali silaturahmi untuk menjalin ukuwah Islamiyah di antara dengan warga sekitar.
\end{abstract}

Kata kunci: hewan qurban, Idul Adha berkurban, keselamatan diri

Abstract
The target and output of this activity are to implement the Tridharma of Higher Education, community
service for lecturers in the Palembang Aviation Polytechnic environment, South Sumatra. The activity
method used is 1) religious lectures, namely spiritual guidance to the Aviation Polytechnic extended family
and local residents; 2) The lecture in which the resource person explained to the Aviation Polytechnic 
extended family and local residents about the wisdom of sacrificing and following the shari'ah of Prophet Ibrahim AS, fostering awareness and participation of the Aviation Polytechnic family and local residents in fostering a love for others in the manifestation of gratitude and piety Allah SWT; and 3) evidence-based learning, in which the "sacrifices" and the implementation team were invited to work together on how to collect, slaughter, and distribute sacrificial animals. The results obtained from this activity can make the implementation team, the Aviation Polytechnic extended family, and residents 1) follow the shari'ah of Prophet Ibrahim AS; 2) Growing awareness and participation of Muslims (lecturers) in fostering a love for others in the manifestation of taqwa to Allah SWT; 3) Serve the community in strengthening ties of friendship to establish ukuwah Islamiah among residents.

Keywords: sacrificial animals, Eid al-Adha sacrifice, personal safety

\section{Pendahuluan}

Allah Swt. berfirman:

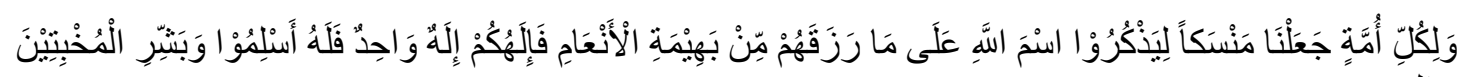

"Dan bagi tiap-tiap umat telah kami syari'atkan penyembelihan (Qurban), supaya mereka menyebut nama Allah terhadap binatang ternak yang telah direzkikan Allah kepada mereka, maka Tuhanmu ialah Tuhan Yang Maha Esa, karena itu berserah dirilah kamu kepada-Nya. Dan berilah kabar gembira kepada orang-orang yang tunduk patuh (kepada Allah).” (QS. Al Hajj: 34)

Allah Swt. juga berfirman:

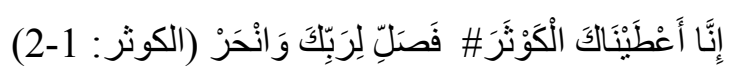

"Sesungguhnya Kami telah memberikan kepadamu ni'mat yang banyak, maka dirikanlah sholat karena Tuhanmu dan ber-kurban-lah.” (QS. Al Kautsar: 1-2).

Rasulullah Saw. bersabda:

"Tidak ada satu amalan yang paling dicintai Allah dari bani Adam ketika hari raya Iedul Adha selain menyembelih hewan qurban. Sesungguhnya hewan qurban itu kelak pada hari kiamat akan datang beserta tanduk-tanduknya, bulu-bulunya dan kukukukunya. Dan sesungguhnya sebelum darah qurban itu menyentuh tanah, ia (pahalanya) telah diterima di sisi Allah, maka beruntunglah kalian semua dengan (pahala) qurban itu." (HR. Tirmidzi, Ibnu Majjah dan Hakim).

Dengan latar belakang firman Alloh Swt. di atas maka sebagai bentuk ihktiar untuk meningkatkan ketaqwaan dan rasa syukur jamaah Musholla Baitul 'Ilmi dan pegawai Politeknik Penerbangan maka kami mengajukan kegiatan Idul Adha $1441 \mathrm{H}$ dalam bentuk pembagian hewan qurban kepada masyarakat di sekitar Politeknik Penerbangan Palembang, sebagai bentuk salah satu implementasi Tridharma Perguruan Tinggi. Dengan mengharapkan Karunia dan Rahmat Allah Swt., serta bertawasul kepada sang Nabi Penutup, Rasulullah Saw., beserta ahli baitnya As., Kami 
Anton Abdullah, Wildan Nugraha, Fitri Masitoh, Sutiyo, Rinto Astutik

Keselamatan Diri dalam Qurban Idul Adha 1441 H sebagai Bentuk Pengabdian kepada Masyarakat

Politeknik Penerbangan Palembang

mengetuk hati para Dermawan Muslimin dan Muslimat Politeknik Penerbangan Palembang, untuk turut membantu demi suksesnya pelaksanaan Kegiatan Idul Adha $1441 \mathrm{H}$.

\section{Metode}

Kegiatan Qurban Idul Adha $1441 \mathrm{H}$ sangat penting sekali bagi Politeknik Penerbangan Palembang sebagai bentuk pengabdian kepada masyarakat disekitarnya. Program ini dibuat dengan harapan mampu membantu menumbuhkan kesadaran dan peran serta dosen di lingkungan Politeknik Penerbangan Palembang dalam menumbuhkan kecintaan kepada sesama dalam perwujudan taqwa kepada Allah Swt., serta mengabdi kepada Masyarakat dalam memperkokoh tali silaturahmi untuk menjalin ukuwah islamiyah diantara dengan warga sekitar.

1. Tujuan

Adapun tujuan kegiatan ini adalah:

1. meneladani syari'at Nabi Ibrahim As.;

2. menumbuhkan kesadaran dan peran serta umat Islam (dosen) dalam menumbuhkan kecintaan kepada sesama dalam perwujudan taqwa kepada Allah Swt.; dan

3. mengabdi kepada masyarakat dalam memperkokoh tali silaturahmi untuk menjalin ukuwah islamiyah diantara dengan warga sekitar.

2. Waktu dan Tempat Pelaksanaan

Kegiatan ini tetap mengedepankan protokol penanganan Covid-19, yang akan dilaksanakan pada:

\begin{tabular}{lll}
\hline Hari / Tanggal & $:$ Sabtu / 1 Agustus 2020 \\
Waktu & $:$ O $07.00-16.00$ WIB / sampai dengan selesai \\
Kegiatan & $:$ Pemotongan Hewan Qurban dan Pembagian Daging Qurban \\
Tempat & $:$ Halaman depan Politeknik Penerbangan Palembang \\
& (Taman Sawit antara GSG dengan Pos Security) \\
\hline
\end{tabular}

3. Ketentuan Pelaksanaan Penanganan Covid-19

1. Penerapan jaga jarak fisik (physical distancing)

a. Pemotongan hanya dilakukan di tempat yang telah disediakan

b. Kepadatan di lokasi penyembelihan di minimalkan, hanya dihadiri oleh panitia danpengkurban

c. Memperhatikan jarak sesuai dengan tanda yang telah disediakan saat melakukan pemotongan, pengulitan, pencacahan, dan pengemasan daging. 
Anton Abdullah, Wildan Nugraha, Fitri Masitoh, Sutiyo, Rinto Astutik

Keselamatan Diri dalam Qurban Idul Adha 1441 H sebagai Bentuk Pengabdian kepada Masyarakat

Politeknik Penerbangan Palembang

d. Pendistribusian daging kurban dilakukan sesuai denagan alur pendistribusian sesuai dengan tanda yanga ada

2. Penerapan kebersihan panitia, meliputi:

a. Pemeriksaan kesehatan awal, yaitu melakukan pengukuran suhu badan di pintu masuk dengan alat pengukur suhu tubuh

b. Penanganan penyembelihan daging tulang dan jeroan sesuai dengan tugas masingmasing yang telah ditetapkan.

c. Penyelenggara/tim pengendali covid selalu mengingatkan pantia atu tim yang laing agar tidak menyentuh seputaran muka/wajah dan telinga, serta sering mencuci tangan dengan sabun.

d. Semua tim/panitia menghindari berjabat tangan /kontak langsung, serta memperhatikan etika batuk/ bersin/ meludah

e. Seluruh tim/panitia harus segera membersihkan diri (mandi) sebelum bertemu anggota keluarga

3. Penerapan kebersihan alat

a. Melakukan pembersihan atau desinfeksi seluruh peralatan sebelum dan sesudah digunakan, serta seluruh area setelah proses penyembelihan kurban

b. Menerapkan sistem satu orang satu alat. Jika tidak memungkinkan maka penggunaan alat lain harus dibersihkan atau disinfeksi terlebih dahulu

Kegiatan ini direncanakan dan akan dilaksanakan selama satu hari. Adapun rincian kegiatan secara garis besar adalah sebagai berikut:

Tabel 1. Rincian Kegiatan

\begin{tabular}{|c|c|c|}
\hline $\begin{array}{c}\text { Hari / } \\
\text { Tanggal }\end{array}$ & Waktu & Kegiatan \\
\hline \multicolumn{2}{|c|}{$\begin{array}{l}\text { PERIODE SEPTEMBER } 2019 \text { sampai } \\
\text { dengan 01-07-2020 }\end{array}$} & $\begin{array}{l}\text { a. } \\
\text { b. pengumpulan pengkurban } \\
\text { c. pengumpulan dana untuk hewan kurban } \\
\text { d. pelunaswan hewan kurban } \\
\text { e. menyiapkan peralatan dan kebutuhan operasional }\end{array}$ \\
\hline \multicolumn{2}{|l|}{$\begin{array}{l}\text { Senin, } \\
20-07-2020\end{array}$} & $\begin{array}{l}\text { a. pembentukan panitia } \\
\text { b. pengumpulan data mustahiq }\end{array}$ \\
\hline $\begin{array}{l}\text { Kamis, } \\
\text { 27-30 Juli } 2020\end{array}$ & 09.00 - selesai & $\begin{array}{l}\text { a. Instalasi dan menyiapkan peralatan dan kebutuhan } \\
\text { operasional } \\
\text { b. Menyiapkan tempat kegiatan: } \\
\text { 1. pembuatan lubang untuk darah sisa pemotongan } \\
\text { 2. pendirian tenda } \\
\text { 3. intalasi lantai terpal untuk pencincangan, penimbangan, } \\
\text { pembungkusan daging qurban sesuai dengan protokol } \\
\text { penanganan covid 19 } \\
\text { c. Menyiapkan sound system dan kebutuhan lainnya }\end{array}$ \\
\hline
\end{tabular}


Anton Abdullah, Wildan Nugraha, Fitri Masitoh, Sutiyo, Rinto Astutik

Keselamatan Diri dalam Qurban Idul Adha 1441 H sebagai Bentuk Pengabdian kepada Masyarakat Politeknik Penerbangan Palembang

\begin{tabular}{|l|l|l|}
\hline $\begin{array}{l}\text { Jumat, } \\
31-07-2020\end{array}$ & Hari tenang (Hari raya Idul Adha 1441 H) \\
\hline Sabtu, \\
$01-08-2020$ & & $\begin{array}{l}\text { Acara Pemotongan dan Pembagian Daging Qurban, dengan } \\
\text { rincian sebagai berikut: }\end{array}$ \\
& & Pengiriman dan penerimaan Hewan Qurban \\
& $05.00-07.30$ & Kultum \\
& $07.30-07.45$ & Sambutan Direktur Poltekbang Palembang atau pejabat yang \\
& $07.45-08.00$ & mewakili \\
& $08.00-12.00$ & Pemotongan Hewan Qurban \\
& $12.00-13.00$ & Ishoma \\
& $13.00-16.00$ & Pembagian Daging Qurban \\
\hline
\end{tabular}

Tabel 2. Alur Persiapan Kegiatan

\begin{tabular}{|c|c|c|c|c|c|c|}
\hline \multirow{4}{*}{ No } & \multirow{4}{*}{$\begin{array}{l}\text { URAIAN } \\
\text { KEGIATAN }\end{array}$} & \multicolumn{4}{|c|}{ PELAKU } & \multirow{4}{*}{ WAKTU } \\
\hline & & \multirow{3}{*}{ PANITIA } & Pengqurban & \multirow{3}{*}{$\begin{array}{l}\text { Bagian } \\
\text { Keuangan }\end{array}$} & \multirow{3}{*}{$\begin{array}{l}\text { Poltekbang } \\
\text { palembang }\end{array}$} & \\
\hline & & & Shodaqoh & & & \\
\hline & & & Pegawai & & & \\
\hline 1. & $\begin{array}{l}\text { Pengumpulan } \\
\text { Pengqurban dan }\end{array}$ & 1 & 1 & & & \\
\hline & Shodaqoh Qurban & & & & & $\begin{array}{l}\text { Akhir } \\
\text { Agustus }\end{array}$ \\
\hline 2. & $\begin{array}{l}\text { Penyerahan list } \\
\text { Pengqurban \& }\end{array}$ & & & 2 & & 2019 \\
\hline & Shodaqoh Qurban & & & & & \\
\hline 3. & $\begin{array}{l}\text { Pemotongan gaji } \\
\text { pengqurban dan }\end{array}$ & & 3 & & & $\begin{array}{c}\text { Awal } \\
\text { September }\end{array}$ \\
\hline 4. & $\begin{array}{l}\text { Laporan keuangan } \\
\text { terkumpul }\end{array}$ & 4 & & 4 & & $\begin{array}{l}\text { Akhir Juni } \\
2020\end{array}$ \\
\hline 5. & $\begin{array}{l}\text { Penawaran } \\
\text { Pengqurban Mandiri }\end{array}$ & & 5 & & & $\begin{array}{l}\text { Awal Juli } \\
2020\end{array}$ \\
\hline 6. & $\begin{array}{l}\text { Rekap total jumlah } \\
\text { pengqurban }\end{array}$ & 6 & & & & $\begin{array}{l}\text { Minggu ke-3 } \\
\text { Juli } 2020\end{array}$ \\
\hline 7. & $\begin{array}{l}\text { Pembuatan \& } \\
\text { pengajuan Proposal } \\
\text { kegiatan Idul Adha } \\
1441 \mathrm{H}\end{array}$ & & & & 7 & $\begin{array}{l}\text { Minggu Ke- } \\
\text { 4 Juli } 2020\end{array}$ \\
\hline
\end{tabular}


Anton Abdullah, Wildan Nugraha, Fitri Masitoh, Sutiyo, Rinto Astutik

Keselamatan Diri dalam Qurban Idul Adha 1441 H sebagai Bentuk Pengabdian kepada Masyarakat Politeknik Penerbangan Palembang

Tabel 3. Alur Pelaksanaan Kegiatan

\begin{tabular}{|c|c|c|c|c|c|c|}
\hline \multirow[b]{2}{*}{ No } & \multirow[b]{2}{*}{ Uraian Kegiatan } & \multicolumn{4}{|c|}{ Pelaku } & \multirow[b]{2}{*}{ Waktu } \\
\hline & & Panitia & $\begin{array}{c}\text { Tim } \\
\text { Pemotong }\end{array}$ & $\begin{array}{c}\text { Direktur } \\
\text { /Pejabat } \\
\text { yang } \\
\text { Mewakili }\end{array}$ & Ustadz & \\
\hline 1. & $\begin{array}{l}\text { Persiapan } \\
\text { operasional kegiatan }\end{array}$ & 1 & & & & $\begin{array}{l}27-30 \text { Juli } \\
2020\end{array}$ \\
\hline 2. & $\begin{array}{l}\text { Pembuatan dan } \\
\text { distribusi kupon } \\
\text { qurban }\end{array}$ & 2 & & & & $\begin{array}{l}27-30 \mathrm{Juli} \\
2020\end{array}$ \\
\hline 3. & $\begin{array}{l}\text { Melengkapi alat dan } \\
\text { bahan kegiatan }\end{array}$ & 3 & & & & $\begin{array}{l}27-30 \text { Juli } \\
2020\end{array}$ \\
\hline 4. & $\begin{array}{l}\text { Menyiapkan tenda } \\
\text { dan semua } \\
\text { kebutuhan kegiatan }\end{array}$ & 4 & & & & $\begin{array}{l}27-30 \\
\text { Juli } 2020\end{array}$ \\
\hline 5. & $\begin{array}{l}\text { Panitia hadir dan } \\
\text { berkumpul di lokasi }\end{array}$ & 5 & & & & $\begin{array}{l}01 \text { Agustus } \\
2020 \\
07.00\end{array}$ \\
\hline 7. & $\begin{array}{l}\text { Prosedur } \\
\text { penanganan COVID } \\
19 \text { oleh tim ke } \\
\text { seluruh panitia } \\
\text { Penerimaan hewan } \\
\text { qurban }\end{array}$ & 7 & & & & $\begin{array}{l}07.00-07.10 \\
07.10-07.20\end{array}$ \\
\hline 8. & $\begin{array}{l}\text { Sambutan direktur } \\
\text { Poltekbang } \\
\text { Palembang / pejabat } \\
\text { yang mewakili }\end{array}$ & & & 8 & & \\
\hline 9. & $\begin{array}{l}\text { Kultum ustadz } \\
\text { dilanjutkan dengan } \\
\text { doa }\end{array}$ & & & & 9 & $07.20-07.30$ \\
\hline 10. & $\begin{array}{l}\text { Penyembelihan } \\
\text { hewan qurban, } \\
\text { Proses pemilhan dan } \\
\text { pembungkusan } \\
\text { daging qurban }\end{array}$ & 10 & 10 & & & $07.30-12.00$ \\
\hline 11. & ISHOMA & 11 & 11 & 11 & 12 & $12.00-13.00$ \\
\hline 12. & Proses pembagian & 12 & & & & $13.00-16.00$ \\
\hline
\end{tabular}

Darmabakti: Jurnal Inovasi Pengabdian dalam Penerbangan 
Anton Abdullah, Wildan Nugraha, Fitri Masitoh, Sutiyo, Rinto Astutik

Keselamatan Diri dalam Qurban Idul Adha 1441 H sebagai Bentuk Pengabdian kepada Masyarakat Politeknik Penerbangan Palembang



Tabel 4. Jenis dan Harga Hewan Qurban Menurut Berat dan Tipe Hewan

\begin{tabular}{|l|c|}
\hline Jenis daging Qurban & Harga \\
\hline Daging sapi 1 & $\mathrm{Rp} 18.000 .000$ \\
Daging sapi 2 & $\mathrm{Rp} 18.000 .000$ \\
Daging sapi 3 & $\mathrm{Rp} 17.000 .000$ \\
Daging sapi 4 & $\mathrm{Rp} 17.000 .000$ \\
Daging sapi 5 & $\mathrm{Rp} 19.000 .000$ \\
Daging sapi 6 & $\mathrm{Rp} 18.000 .000$ \\
Daging sapi 7 & $\mathrm{Rp} 18.000 .000$ \\
Daging Kambing 1 & $\mathrm{Rp} 3.000 .000$ \\
Daging Kambing 2 & mandiri \\
\hline
\end{tabular}

\section{Pengkurban}

Terdiri dari 37 orang pegawai Politeknik Penerbangan Palembang (baik ASN maupun PUPNS) yang secara sukarela menyumbangkan dalam bentuk tabungan yang besarannya bervariasi karena sifatnya sukarela dan tidak mengikat. Shodaqoh Qurban diperuntukkan untuk memberikan porsi pada pengkurban. Nama yang dipilih dalam porsi pengkurban tersebut diambil dari nama pegawai Politeknik Penerbangan Palembang non ASN/PUPNS yang di pandang perlu menerima bantuan, sehingga berkesempatan untuk berkurban.

Tabel 5. Pengqurban

\begin{tabular}{|c|l|l|l|}
\hline \multicolumn{2}{|c|}{ SAPI 1 } & \multicolumn{1}{c|}{ SAPI 2 } & \multicolumn{1}{c|}{ SAPI 3 } \\
\hline 1 & Virma Septiani & Direstu Amalia & Titut \\
\hline 2 & M. Rensi Koswara & Sutiyo & Denny \\
\hline 3 & Ria Maya Sari & Wulan Widiya Rahayu & Rita Zahara \\
\hline 4 & Wildan Nugraha & Sahyumar Lisbo A & Supartono \\
\hline 5 & Herlina Febiyanti & Rara DP & Retno A \\
\hline
\end{tabular}


Anton Abdullah, Wildan Nugraha, Fitri Masitoh, Sutiyo, Rinto Astutik

Keselamatan Diri dalam Qurban Idul Adha 1441 H sebagai Bentuk Pengabdian kepada Masyarakat Politeknik Penerbangan Palembang

\begin{tabular}{|c|l|l|l|}
6 & Anton Abdullah 1 & Wahyudi Saputra & Dwi Candra Yuniar \\
\hline 7 & Kiswanto & dr.Yessy Budiarti & Susi Prihartini \\
\hline SAPI 4 & SAPI 5 & SAPI 6 \\
\hline 1 & Ramlan & Pratiwi Dwi Utami & Asep M. Soleh \\
\hline 2 & Dini Desti Maulani & Wasini & Shodaqoh Qurban 2 \\
\hline 3 & Viktor Suryan & Sri Harnita & Jafar Haris M. \\
\hline 4 & Rinto Astutik & Fitri Masitoh & Kosim 1 \\
\hline 5 & M. Erawan Destiana & Bu Yanti 1 & Kosim 2 \\
\hline 6 & Eliya & Bu Yanti 2 & Kosim 3 \\
\hline 7 & Shodaqoh Qurban 1 & Yessy 2 & Kosim 4 \\
\hline \multicolumn{2}{|l|}{ SAPI 7 } & KAMBING 1 & KAMBING 2 \\
\hline 1 & Pak Kosim 5 & Pokja ULP SUMSEL & Ayu Putri Wijaya \\
\hline 2 & Yudi 1 & & \\
\hline 3 & Yudi 2 & & \\
\hline 4 & Yudi 3 & & \\
\hline 5 & Anton Abdullah 2 & \\
\hline 6 & Anton Abdullah 3 & \\
\hline 7 & Anton Abdullah 4 & \\
\cline { 1 - 1 } & & & \\
\end{tabular}

Setiap responden diberikan 1 kali kesempatan untuk memilih 1 pilihan Calon Pengqurban dari Shodaqoh Qurban di bawah ini. BATAS WAKTU PENILAIAN/PEMILIHAN INI SAMPAI DENGAN SENIN, 13 JULI 2020 PUKUL 12.00 WIB. Nama responden bersifat rahasia dan tidak diketahui. KEPUTUSAN HASIL AKHIR ADALAH MUTLAK DARI PILIHAN BAPAK IBU.

31 responses
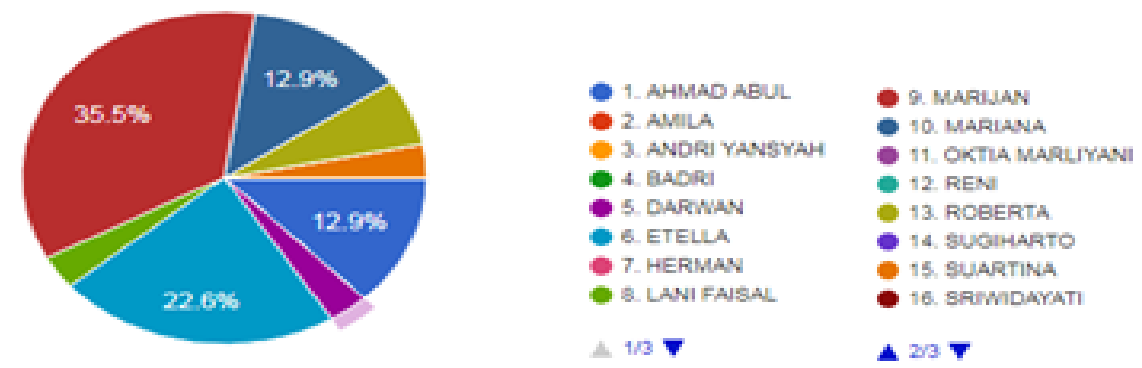

17. TUTI SURYANTI

Gambar 1. Hasil Voting Shodaqoh Qurban

Tabel 6. Hasil Voting Shodaqoh Qurban

\begin{tabular}{|l|c|l|c|c|}
\hline No. & No. Urut & Nama & Jumlah pemilih & Persentase Perolehan \\
\hline 1. & 9 & Marijan & 11 & $35,5 \%$ \\
\hline 2. & 6 & Etella & 7 & $22,6 \%$ \\
\hline 3. & 1 & Ahmad Abul & 4 & $12,9 \%$ \\
\hline 4. & 10 & Mariana & 4 & $12,9 \%$ \\
\hline 5. & 13 & Roberta & 2 & $6,5 \%$ \\
\hline 6. & 15 & Suartina & 1 & $3,2 \%$ \\
\hline 7. & 5 & Darwan & 1 & $3,2 \%$ \\
\hline 8. & 8 & Lani Faisal & 1 & $3,2 \%$ \\
\hline \multicolumn{2}{|c|}{ TOTAL } & 31 & $100 \%$ \\
\hline
\end{tabular}


Anton Abdullah, Wildan Nugraha, Fitri Masitoh, Sutiyo, Rinto Astutik

Keselamatan Diri dalam Qurban Idul Adha 1441 H sebagai Bentuk Pengabdian kepada Masyarakat Politeknik Penerbangan Palembang

Dari hasil tersebut diatas maka diputuskan nama porsi pengqurban $1441 \mathrm{H}$ mushola Baitul 'Ilmi Politeknik Penerbangan Palembang, yaitu:

1. Bapak Marijan untuk porsi Sapi 4

2. Bapak Etella untuk porsi Sapi 6

\section{Biaya}

Sumber dana kegiatan ini berasal dari tabungan Qurban dan shodaqoh pegawai Politeknik Penerbangan Palembang yang telah dikumpulkan dari bulan Juni 2019 sampai dengan Bulan Juli 2020. Dana yang terkumpul dari 26 orang penabung Qurban adalah sebesar Rp. 71.500.000. (21 orang pengquban mandiri sebesar Rp. 58.000.000 dan 37 orang shodaqoh qurban sebesar Rp. 4.500.000). Jadi total dana yang terkumpul sebesar Rp. 134.000.000. dengan rincian sebagai berikut:

Tabel 7. Rencana Biaya

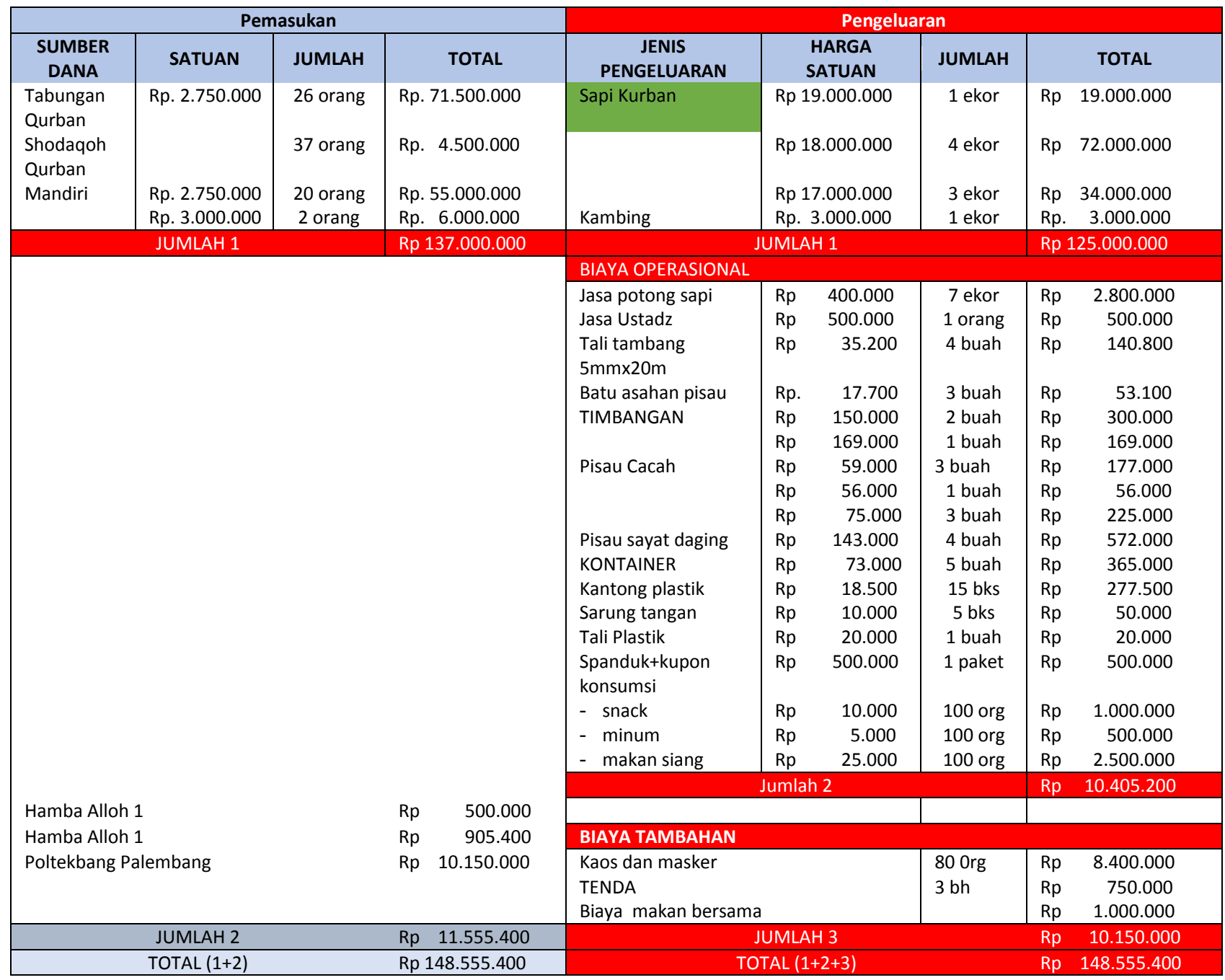


Anton Abdullah, Wildan Nugraha, Fitri Masitoh, Sutiyo, Rinto Astutik

Keselamatan Diri dalam Qurban Idul Adha 1441 H sebagai Bentuk Pengabdian kepada Masyarakat Politeknik Penerbangan Palembang

\section{Hasil dan Pembahasan}

Pada tahap pengumpulan pengqurban, umat muslim Poltekbang Palembang sangat antusias, hal ini terlihat dari jumlah porsi pengqurban, tidak hanya dosen ataupun ASN, tetapi pengqurban juga diikuti dari beberapa pegawai non ASN, bahkan dari sebagian besar pegawai yang belum tergabung juga mengisyratkan bahwa mereka akan tertarik di kegiatan tahun berikutnya.

Kemudian di tahap persiapan pelaksanaan, terlihat antusias sekali untuk ikut juga aktif dalam kegiatan ini, walaupun bukan sebagai pengqurban. Di tahap ini, dilakukan pembekalan mengenai pentingnya berqurban, dan bagaimana menyiapkan segala sesuatunya agar kegiatan pelaksanaan bisa berjalan dengan baik. Indikator lainnya adalah suasana terlihat hidup dengan adanya sesi tanya jawab dan diskusi tentang beberapa tahapan dari seperti deskripsi kondisi awal, mencari dan mengumpulkan pengqurban, menyiapkan alat, bahan dan lokasi, teknik penyembelihan, penyayatan dan pengepakan hewan qurban, teknik perhitungan sementara jumlah daging qurban. Dengan adanya kegiantan ini para dosen dan pelaksana terlihat bersemangat dalam memulai bimbingan pelaksanaan. Upaya yang dilakukan pada prinsipnya lebih ditekankan pada memotivasi dan melibatkan kegiatan peserta pelaksana. Oleh karena itu model kegiatan ini dianggap lebih efektif karena para dosen dilibatkan secara aktif berlatih dan berkarya tidak hanya mendengarkan ceramah yang hanya bersifat transfer pengetahuan, didampingi para dosen yang selalu mengarahkan dan memotivasi hingga pelaksana kegiatan benar-benar mampu melaksanakan kegiatan merupakan hasil refleksi dari permasalahan yang mereka temui. Hasil dari kegiatan ini telah terbagi daging qurban sebanyak $533 \mathrm{~kg}$ yang di bagi dalam tiga kemasan dengan rincian sebagai berikut:

Tabel 8. Perkiraan Daging Qurban yang Didapat dan Perolehan Daging Qurban di Lapangan

\begin{tabular}{|c|c|c|}
\hline \multirow{2}{*}{ Jenis daging Qurban } & \multicolumn{2}{|c|}{ Perolehan Daging } \\
\hline & Perkiraan & Real (Dilapangan) \\
\hline Daging sapi 1 & $70 \quad \mathrm{Kg}$ & $67 \mathrm{Kg}$ \\
\hline Daging sapi 2 & $70 \mathrm{Kg}$ & $63 \mathrm{Kg}$ \\
\hline Daging sapi 3 & $60 \mathrm{Kg}$ & $84 \mathrm{Kg}$ \\
\hline Daging sapi 4 & $60 \mathrm{Kg}$ & $75 \mathrm{Kg}$ \\
\hline Daging sapi 5 & $70 \mathrm{Kg}$ & $108 \mathrm{Kg}$ \\
\hline Daging sapi 6 & $70 \mathrm{Kg}$ & $66 \mathrm{Kg}$ \\
\hline Daging sapi 7 & $70 \mathrm{Kg}$ & $76 \mathrm{Kg}$ \\
\hline Daging Kambing 1 & $7 \mathrm{Kg}$ & $7 \mathrm{Kg}$ \\
\hline Daging Kambing 2 & $7 \mathrm{Kg}$ & $7 \mathrm{Kg}$ \\
\hline Total Perolehan Daging Qurban & $484 \mathrm{Kg}$ & $553 \mathrm{Kg}$ \\
\hline
\end{tabular}


Anton Abdullah, Wildan Nugraha, Fitri Masitoh, Sutiyo, Rinto Astutik

Keselamatan Diri dalam Qurban Idul Adha 1441 H sebagai Bentuk Pengabdian kepada Masyarakat Politeknik Penerbangan Palembang

Tabel 9. Pembagian Daging Qurbang di Lapangan

\begin{tabular}{|c|c|c|c|c|c|c|c|c|c|c|}
\hline No. & $\begin{array}{c}\text { Estimasi Pembagian Daging } \\
\text { Qurban } \\
\end{array}$ & $\begin{array}{r}\mathrm{Uk} \mathrm{l} \\
\mathrm{Kg} / \mathrm{I}\end{array}$ & & $\begin{array}{l}\text { BKS per } \\
\text { Orang }\end{array}$ & Jumla & Orang & $\begin{array}{r}\text { Jun } \\
\text { Dagin }\end{array}$ & lah & & $\begin{array}{l}\text { nlah } \\
\text { Kupon }\end{array}$ \\
\hline 1 & Pengqurban SAPI $3 \mathrm{~kg} / \mathrm{BKS}$ & & $\mathrm{Kg}$ & $\begin{array}{ll}3 & \text { BKS }\end{array}$ & 32 & orang & 96 & $\mathrm{~kg}$ & 96 & BKS \\
\hline 2 & Pengqurban SAPI $2 \mathrm{~kg} / \mathrm{BKS}$ & 1 & $\mathrm{Kg}$ & 2 BKS & 5 & orang & 10 & $\mathrm{~kg}$ & 10 & BKS \\
\hline 3 & Pengqurban SAPI $1 \mathrm{~kg} / \mathrm{BKS}$ & 1 & $\mathrm{Kg}$ & 1 BKS & 10 & orang & 10 & $\mathrm{~kg}$ & 10 & BKS \\
\hline 5 & Mustahiq PNS & 0,8 & $\mathrm{Kg}$ & $1 \mathrm{BKS}$ & 30 & orang & 24 & $\mathrm{~kg}$ & 30 & BKS \\
\hline 6 & Mustahiq PUPNS & 0,8 & $\mathrm{Kg}$ & $1 \quad \mathrm{BKS}$ & 31 & orang & 25 & $\mathrm{~kg}$ & 31 & BKS \\
\hline 7 & $\begin{array}{l}\text { Mustahiq CLEANING } \\
\text { SERVICE }\end{array}$ & 0,8 & $\mathrm{Kg}$ & 1 BKS & 15 & orang & 12 & $\mathrm{~kg}$ & 15 & BKS \\
\hline 8 & Bude Tono Crew & 0,8 & $\mathrm{Kg}$ & $1 \quad \mathrm{BKS}$ & 12 & orang & 10 & $\mathrm{~kg}$ & 12 & BKS \\
\hline 9 & $\begin{array}{l}\text { Tukang Bangunan } \\
\text { Perpustakaan }\end{array}$ & 0,8 & $\mathrm{Kg}$ & $1 \quad$ BKS & 40 & orang & 32 & $\mathrm{~kg}$ & 40 & BKS \\
\hline 10 & $\begin{array}{l}\text { Tukang Pemeliharaan } \\
\text { Diyang+Deny }\end{array}$ & 0,8 & $\mathrm{Kg}$ & 1 BKS & 3 & orang & 2 & $\mathrm{~kg}$ & 3 & BKS \\
\hline 11 & Tukang Pemeliharaan It & 0,8 & $\mathrm{Kg}$ & $1 \quad \mathrm{BKS}$ & 4 & orang & 3 & $\mathrm{~kg}$ & 4 & BKS \\
\hline 12 & Tukang Pemeliharaan & 0,8 & $\mathrm{Kg}$ & 1 BKS & 12 & orang & 10 & $\mathrm{~kg}$ & 12 & BKS \\
\hline 13 & Tukang Potong Rumput & 0,8 & $\mathrm{Kg}$ & $1 \mathrm{BKS}$ & 1 & orang & 1 & $\mathrm{~kg}$ & 1 & BKS \\
\hline 14 & $\begin{array}{l}\text { Tukang Tangki Air + Galon } \\
\text { Air }\end{array}$ & 0,8 & $\mathrm{Kg}$ & $1 \mathrm{BKS}$ & 1 & orang & 1 & $\mathrm{~kg}$ & 1 & BKS \\
\hline 15 & $\begin{array}{l}\text { Tukang Sampah Diklat Dan } \\
\text { Komplek }\end{array}$ & 0,8 & $\mathrm{Kg}$ & 1 BKS & 5 & orang & 4 & $\mathrm{~kg}$ & 5 & BKS \\
\hline 16 & $\begin{array}{l}\text { Ibu-Ibu Penyapu Jalan Depan } \\
\text { Diklat }\end{array}$ & 0,8 & $\mathrm{Kg}$ & 1 BKS & 2 & orang & 2 & $\mathrm{~kg}$ & 2 & BKS \\
\hline 17 & Tim Auri & 0,8 & $\mathrm{Kg}$ & $1 \mathrm{BKS}$ & 5 & orang & 4 & $\mathrm{~kg}$ & 5 & BKS \\
\hline 18 & $\begin{array}{l}\text { Asisten Rumah Tangga } \\
\text { Komplek Diklat }\end{array}$ & 0,8 & $\mathrm{Kg}$ & $1 \quad \mathrm{BKS}$ & 2 & orang & 2 & $\mathrm{~kg}$ & 2 & BKS \\
\hline 19 & Warga Buaran & 0,8 & $\mathrm{Kg}$ & 1 BKS & 125 & orang & 100 & $\mathrm{~kg}$ & 125 & BKS \\
\hline 20 & Warga Rt. 16 & 0,8 & $\mathrm{Kg}$ & 1 BKS & 20 & orang & 16 & $\mathrm{~kg}$ & 20 & BKS \\
\hline 21 & $\begin{array}{l}\text { Warga Rt. } 17 \text { Deket Dengan } \\
\text { Diklat }\end{array}$ & 0,8 & $\mathrm{Kg}$ & $1 \mathrm{BKS}$ & 15 & orang & 12 & $\mathrm{~kg}$ & 15 & BKS \\
\hline 22 & Warga Abdul Aziz & 0,8 & $\mathrm{Kg}$ & $1 \mathrm{BKS}$ & 30 & orang & 24 & $\mathrm{~kg}$ & 30 & BKS \\
\hline 23 & Warga Jl. Cempaka (Rt. 21) & 0,5 & $\mathrm{Kg}$ & 1 BKS & 15 & orang & 8 & $\mathrm{~kg}$ & 15 & BKS \\
\hline 24 & Pensiunan & 0,5 & $\mathrm{Kg}$ & 1 BKS & 6 & orang & 3 & $\mathrm{~kg}$ & 6 & BKS \\
\hline 25 & Tkg Bakso,Gado ${ }^{2}$, Model & 0,5 & $\mathrm{Kg}$ & $1 \quad \mathrm{BKS}$ & 2 & orang & 1 & $\mathrm{~kg}$ & 2 & BKS \\
\hline 26 & Warga Rt. 18 & 0,5 & $\mathrm{Kg}$ & $1 \quad$ BKS & 67 & orang & 34 & $\mathrm{~kg}$ & 67 & BKS \\
\hline 27 & Warga Rt. 20 & 0,5 & $\mathrm{Kg}$ & $1 \quad \mathrm{BKS}$ & 4 & orang & 2 & $\mathrm{~kg}$ & 4 & BKS \\
\hline 28 & Warga Rt. 17 & 0,5 & $\mathrm{Kg}$ & $1 \mathrm{BKS}$ & 21 & orang & 11 & $\mathrm{~kg}$ & 21 & BKS \\
\hline \multicolumn{5}{|c|}{ JUMLAH 1} & 515 & orang & 456 & & 584 & $\begin{array}{l}\text { BKS/ } \\
\text { kupon }\end{array}$ \\
\hline \multicolumn{9}{|c|}{ KUPON/BUNGKUS TAK TERBAGI } & 14 & $\begin{array}{l}\text { BKS/ } \\
\text { kupon }\end{array}$ \\
\hline 29 & panti asuhan Rizky Raisyah & 0,5 & $\mathrm{Kg}$ & & & & 4,5 & $\mathrm{~kg}$ & 9 & BKS \\
\hline 30 & panti asuhan Al-Islam & & $\mathrm{Kg}$ & & & & 4,5 & $\mathrm{~kg}$ & 9 & BKS \\
\hline 31 & panti asuhan $\mathrm{Al}$ Umroh & 0,5 & $\mathrm{Kg}$ & & & & 4,5 & $\mathrm{~kg}$ & 9 & BKS \\
\hline 32 & panti asuhan An-Nur & 0,5 & $\mathrm{Kg}$ & & & & 4,5 & $\mathrm{~kg}$ & 9 & BKS \\
\hline \multicolumn{5}{|c|}{ JUMLAH 2} & & & 18 & $\mathrm{~kg}$ & 36 & BKS \\
\hline 33 & $\begin{array}{l}\text { Makan Bersama (12 BKS Sapi } \\
+7 \text { BKS Kbg) }\end{array}$ & & & & & & 10 & & 19 & BKS \\
\hline 34 & Tanpa Kupon & 0,5 & $\mathrm{Kg}$ & & & & 14 & $\mathrm{~kg}$ & 28 & BKS \\
\hline 35 & $\begin{array}{l}\text { Toleransi Kesalahan Timbang } \\
10 \%\end{array}$ & & & & & & 55 & $\mathrm{~kg}$ & 111 & BKS \\
\hline \multicolumn{5}{|c|}{ Jumlah 3} & & & 79 & $\mathrm{~kg}$ & 158 & BKS \\
\hline \multicolumn{5}{|c|}{ Total Daging Terbagi $(1+2+3)$} & & & 533 & kg & 736 & BKS \\
\hline
\end{tabular}


Anton Abdullah, Wildan Nugraha, Fitri Masitoh, Sutiyo, Rinto Astutik

Keselamatan Diri dalam Qurban Idul Adha 1441 H sebagai Bentuk Pengabdian kepada Masyarakat Politeknik Penerbangan Palembang

Tabel 10. Rekapitulasi Pembagian Daging Qurban

\begin{tabular}{|c|c|c|c|c|c|c|c|}
\hline \multicolumn{3}{|c|}{ Perolehan Daging di Lapangan } & \multicolumn{5}{|c|}{ Pembagian dagIng di Lapangan } \\
\hline Daging sapi 1 & 67 & $\mathrm{Kg}$ & $\begin{array}{l}\text { Jatah pengqurban } \\
\text { (@1 kg/bks) }\end{array}$ & 116 & $\mathrm{~kg}$ & 116 & Bks/kupon \\
\hline Daging sapi 2 & 63 & $\mathrm{Kg}$ & Mustahiq (@0,8kg/bks) & 282 & $\mathrm{~kg}$ & 353 & bks/kupon \\
\hline Daging sapi 3 & 84 & $\mathrm{Kg}$ & Mustahiq (@0,5kg/bks) & 58 & $\mathrm{~kg}$ & 115 & bks/kupon \\
\hline Daging sapi 4 & 75 & $\mathrm{Kg}$ & Jumlah 1 (kupon) & 456 & kg & 584 & bks/kupon \\
\hline Daging sapi 5 & 108 & $\mathrm{Kg}$ & & & & & \\
\hline Daging sapi 6 & 66 & $\mathrm{Kg}$ & Panti Asuhan(@0,5kg/bks) & 18 & $\mathrm{~kg}$ & 36 & Bks \\
\hline Daging sapi 7 & 76 & $\mathrm{Kg}$ & Makan bersama & 10 & $\mathrm{~kg}$ & 19 & BKS \\
\hline Daging Kambing 1 & 7 & $\mathrm{Kg}$ & Tanpa kupon & 14 & $\mathrm{~kg}$ & 28 & BKS \\
\hline \multirow[t]{2}{*}{ Daging Kambing 2} & 7 & $\mathrm{Kg}$ & $\begin{array}{l}\text { Toleransi Kesalahan } \\
\text { Timbang } 10 \%\end{array}$ & 55 & $\mathrm{~kg}$ & 111 & BKS \\
\hline & & & Jumlah 2 (tanpa kupon) & 79 & kg & 158 & BKS \\
\hline $\begin{array}{c}\text { Total perolehan } \\
\text { daging }\end{array}$ & 553 & $\mathrm{Kg}$ & Jumlah total $(1+2)$ & 553 & $\mathrm{~kg}$ & 778 & BKS \\
\hline
\end{tabular}

Beberapa dokumentasi pelaksanaan kegiatan Qurban Idul Adha $1441 \mathrm{H}$ dosen Prodi DIII PPKP Politeknik Penerbangan Palembang Tahun 2020, sebagai berikut:

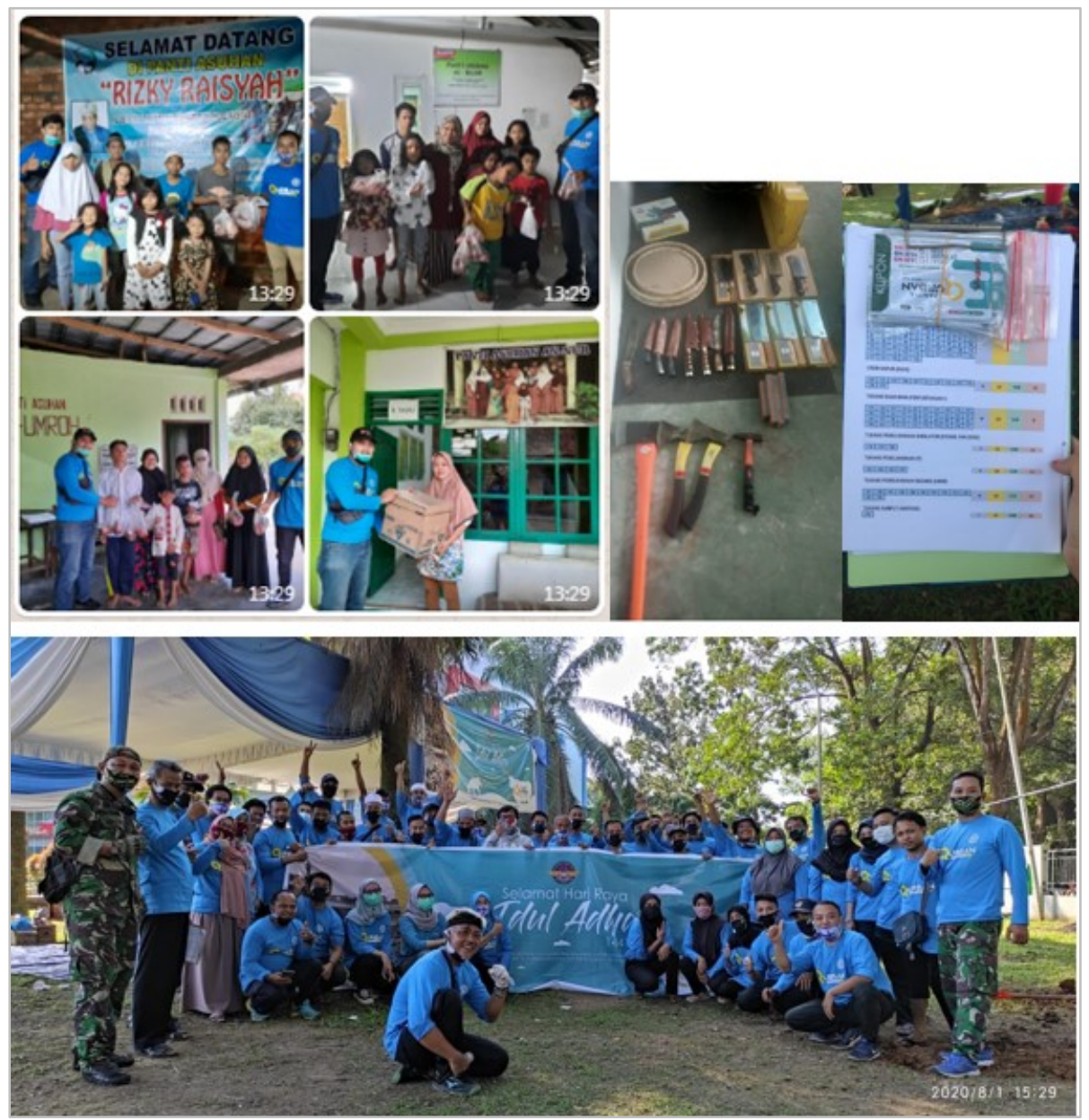


Anton Abdullah, Wildan Nugraha, Fitri Masitoh, Sutiyo, Rinto Astutik

Keselamatan Diri dalam Qurban Idul Adha 1441 H sebagai Bentuk Pengabdian kepada Masyarakat Politeknik Penerbangan Palembang


Gambar 2. Dokumentasi Pelaksanaan Kegiatan 
Anton Abdullah, Wildan Nugraha, Fitri Masitoh, Sutiyo, Rinto Astutik

Keselamatan Diri dalam Qurban Idul Adha 1441 H sebagai Bentuk Pengabdian kepada Masyarakat Politeknik Penerbangan Palembang

\section{Kesimpulan}

Kegiatan Qurban Idul Adha $1441 \mathrm{H}$ dosen Prodi DIII PPKP Politeknik Penerbangan Palembang Tahun 2020 merupakan salah satu kegiatan meningkatkan kompetensi dosen dalam pengabdian kepada masyarakat. Hasil yang diperoleh dari kegiatan ini dapat membuat peserta (dosen), yaitu: 1) meneladani syari'at Nabi Ibrahim As. dan 2) menumbuhkan kesadaran dan peran serta umat Islam (dosen) dalam menumbuhkan kecintaan kepada sesama dalam perwujudan taqwa kepada Allah Swt.

Saran yang dapat disampaikan berkaitan dengan hasil pelaksanaan kegiatan ini dipapakar adalah: 1) Sebaiknya kegiatan Qurban Idul Adha dosen Politeknik Penerbangan Palembang Tahun 2020 ini dapat dilaksanakan secara periodik dan berkesinambungan. Oleh karena itu, kegiatan ini hendaknya ditindaklanjuti dengan kegiatan pengabdian berikutnya; dan 2) Peserta kegiatan ini hendaknya menjangkau semua dosen yang ada di Politeknik Penerbangan Palembang.

\section{Ucapan Terima Kasih}

Ucapan terimakasih yang sebesar-besarnya kami tujukan kepada Lurah Sukodadi, para Ketua RT dan RW Kelurahan Sukodadi, keamanan dan Babinsa Kelurahan Sukodadi, Direktur, Kapus PPM, beserta jajarannya yang telah memfasilitasi dan memberikan kesempatan kepada Tim pelaksana kegiatan untuk melaksanakan kegiatan pengabdian masyarakat tersebut. Mudah-mudahan kegiatan ini dapat bermanfaat bagi masyarakat sekitar Politeknik Penerbangan Palembang.

\section{Daftar Pustaka}

Abdullah, A. (2020). Relationship the Work Culture and Training Programs Within Performance. International Journal of Progressive Sciences and Technologies, 20(1), 92101.

Alquran: Al Kautsar, 1-2.

Alquran: Al Hajj, 34.

HR. Tirmidzi, Ibnu Majjah dan Hakim. Alhadist. 